\title{
Peter Kristjan Iversen
}

\author{
$1914-23$. maj - 1994
}

\section{af Troels Fink}

På sin 80 års fødselsdag kan Peter Kristjan Iversen se tilbage på lang og tro tjeneste for sit danske fædreland og for sin sønderjyske hjemstavn. Hans snævre hjemstavn er det gamle enklavesogn Møgeltender. Den landsby, han kommer fra, hedder Bønderby, og han har rod i gammel bondetradition; han har leveret talrige bidrag til sønderjysk landbrugshistorie, men hans interesser rækker langt videre. Udover det umiskendelige talent for videnskabeligt arbejde har han et sjældent organisationstalent og dertil en klar opfattelse af de skiftende krav, tiden har stillet.

Iversen havde den lykke på gymnasiet i Tonder at få en kreds af fremragende pædagoger som lærere. Hvad lærerstaben angik, var Statsskolen i Tønder nok det heldigste af de gymnasier, som blev nyoprettet i Sønderjylland efter genforeningen. Efter embedseksamen i Aarhus blev han i 1944 knyttet til det sønderjyske landsarkiv, som han fra 1960-81 var chef for. Det oplevede en grødefuld tilværelse $\mathrm{i}$ denne tid $\mathrm{i}$ årene før nedskæringerne satte ind.

I 1946 blev han sekretær for Historisk Samfund for Sønderjylland. Han tjente foreningen i mange år, i flere omgange som formand. Han ikke alene tjente foreningen, han fornyede den. Han havde de visioner der førte til, at foreningen blev reorganiseret. Da P. Kr. Iversen i 1946 blev sekretær, var amtslæge, dr. Lausten-Thomsen foreningens formand. Sekretær og formand kom godt ud af det med hinanden, men de reformplaner, som den unge sekretær forelagde i begyndelsen af 1950 'erne, syntes formanden slet ikke om, og alligevel blev de gennemført. Iversen ville dele opgaverne op i tre dele: 1) Det folkelige historiske arbejde; der var herved især tænkt på foredrag, udflugter, byvandringer m.m. 2) Det lokalhistoriske arbejde; der var herved tænkt på stoffet til Sønderjyske Årbøger og Sønderjysk Månedsskrift og 3) Det videnskabelige arbejde; her var der særlig tænkt på skriftrækken indbefattet kildepublikationer. Netop forbindelsen mellem det folkelige og det videnskabelige var - og er - et særkende for Historisk Samfund for Sønderjylland.

Efter Iversens plan skulle opgaverne fordeles således, at bestyrelsesmedlemmerne deltog i arbejdet i forskellige udvalg og i redaktionerne. Princippet var, at hvert bestyrelsesmedlem skulle have en særlig opgave. Det andet hovedmoment i planen var, at medlemmerne skulle fordeles på amtskredse, hver med 


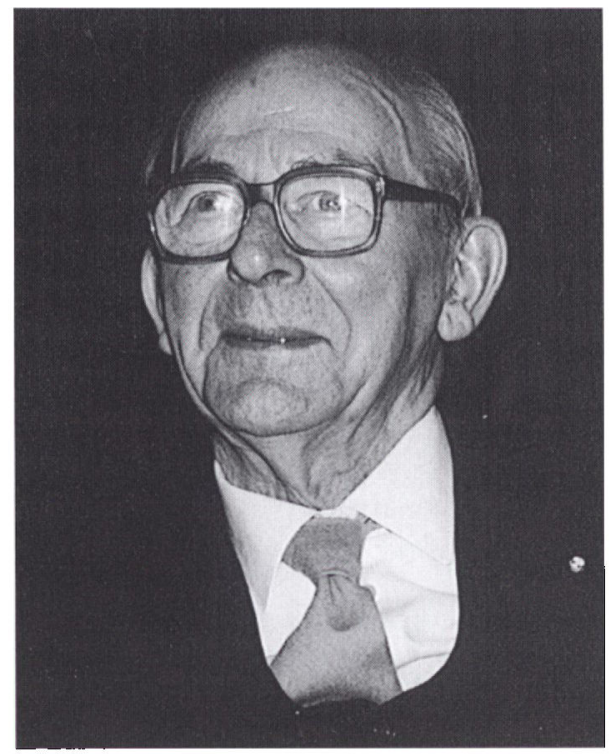

Peter Kr. Iversen fotograferet i 1993. Privateje.

sin særlige bestyrelse. I disse kredse kunne de folkelige opgaver tages op og derved kontakten til medlemmerne styrkes. Der blev oprettet en amtskreds for hvert af de gamle sønderjyske amter og en kreds for Sydslesvig. Derved blev Historisk Samfund en af de få organisationer, der ligeligt omfatter både Nordog Sydslesvig. Formændene for amtskredsene blev medlemmer af hovedbestyrelsen.

Planen mødte almindelig sympati i bestyrelsen, da den i 1954 blev forelagt, undtagen hos formanden. Den blev endelig vedtaget i 1955; én stemte imod; det var formanden, som dog blev på sin post et år endnu.

Med reorganisationen blev Historisk Samfund i stand til at løse langt flere opgaver end tidligere. Tidsmæssigt faldt reformen sammen med, at tyngdepunktet for sønderjysk historisk forskning nu kom til at ligge $i$ landsdelen selv.

Som den politiske udvikling havde formet sig, var de sønderjyske problemer i mindre grad et landsanliggende end de tidligere havde været. Dr. LaustenThomsen havde ved flere lejligheder beklaget, at de danske universiteter ikke viste Sønderjyllands historie samme interesse som tidligere. Da Iversen i 1954 fremlagde sine reformplaner, tog han også stilling til denne side af sagen, idet han skrev: "Jeg har spurgt mig selv, om Historisk Samfund for Sønderjylland ved en omlægning af arbejdet kunne yde et bidrag til, at det historiske arbejde i grænselandet $\mathrm{i}$ dets forskellige afskygninger kunne intensiveres og fremmes. 
Det er min opfattelse, at forinden vi retter anker mod andre og stiller krav om større understøttelse til studiet af sønderjysk historie, må vi først gribe i vor egen barm og undersøge, om Historisk Samfund ved en samling af kræfterne og ved opdeling af opgaverne kunne yde mere end vi hidtil har gjort 4 .

Denne forventning gik i høj grad i opfyldelse. En hel række sønderjyske historikere, der i kraft af genforeningen havde fået gode muligheder for uddannelse og studier, kom til at sætte deres tydelige præg på sønderjysk historieforskning siden 1940'erne. Lad mig blot nævne Hans Hejselbjerg Paulsen, Gottlieb Japsen, Hans Neumann og H. V. Gregersen. Til denne kreds må man også medregne P. Kr. Iversen.

Da reorganisationen af Historisk Samfund for Sønderjylland var vel gennemført, tog P. Kr. Iversen endnu en ny organisatorisk opgave op, idet han med henblik på at indsamle billeder og traditionsstof m.m. i efteråret $1960 \mathrm{fik}$

Flere boger, mange storre og mindre artikler og digre kildeudgivelser er der blevet tid og krafter til $i$ det virksomme otium. Det er der mange forklaringer $p d$ ogsd et velfungerende "bagland". Mathea og Peter Kr.Iversen fotograferet 1989. Privateje.

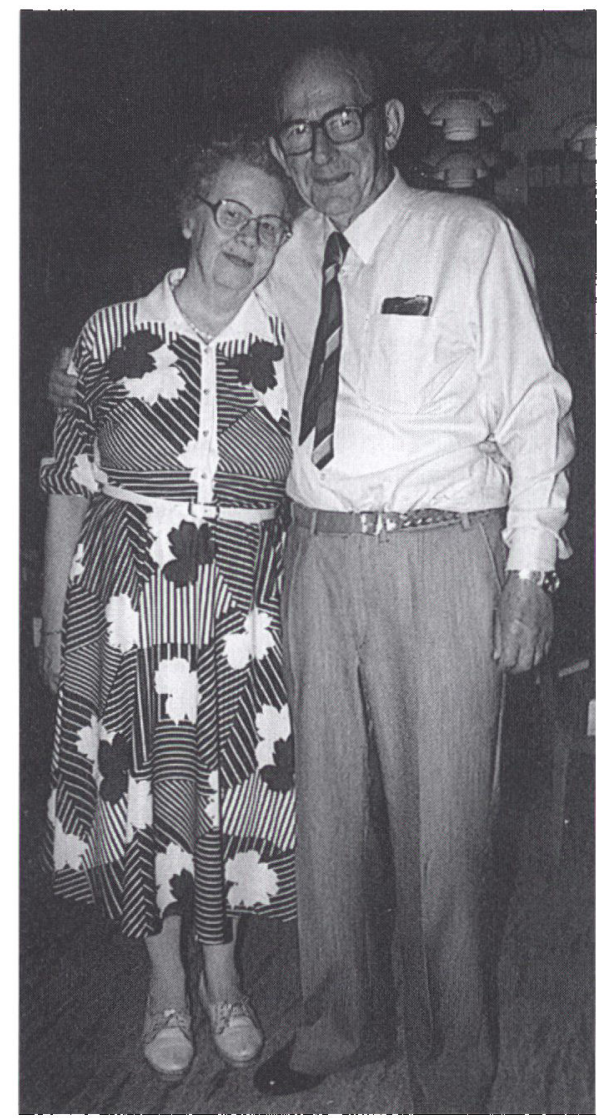


oprettet »Historiske Samlinger for Sønderjylland«. Det krævede al Iversens stædighed at få råbt Kulturministeriet op, og da der endelig kom et bidrag til at løse opgaverne, var det meget beskedent. Men Iversen forstod at få en række fonde til at fremme sagen, og han formåede også at skaffe gratis arbejdskraft. Sidst i 1960 'erne besluttede amt og kommuner at give 10 øre pr. indbygger i tilskud til arbejdet i Historisk Samfund for Sønderjylland, en post som amtskommunen efter kommunalreformen i 1970 har overtaget. Beløbet blev sat op fra 10 til 15 øre pr. indbygger, og i dag udgør det årligt $75.000 \mathrm{kr}$.

Takket være Iversens energi kom samlingerne i god gænge, billedernes og båndoptagelsernes antal voksede støt. Der blev $\mathrm{i}$ forbindelse med Landsarkivets udvidelse skaffet gode lokaler, og Iversen har haft den glæde, at "Samlingerne « nu er et veletableret foretagende, der lever $i$ bedste velgående under navnet »Institut for sønderjysk Lokalhistorie«.

Uanset de store organisatoriske opgaver ved siden af en krævende embedsgerning $\mathrm{i}$ arkivets tjeneste er der fra Iversens hånd kommet talrige bidrag til sønderjysk historie; især landbrugshistorien har haft hans interesse. Adskillige arbejder vedrører det Schackenborgske godsområde, men også hovedgårdene på Als har han vist sin interesse. Til artikler og bøger slutter sig en række værdifulde udgivelser, bl.a. "Kniplingskræmmer Jens Wulffs dagbog«. Senest har han udgivet "Revision over Gram og Nybøl godser 1761. « Endnu et stort udgiverarbejde hviler på Iversens skuldre; det er to bind af de Hansborgske registranter indeholdende de af hertug Hans den Ældre afsagte domme i perioden 1544-80. Denne udgivelse blev for mange år siden planlagt af arkivar Caroline Emilie Andersen. P. Kr. Iversen og undertegnede påtog sig i 1950'erne hvervet som tilsynsførende; men $\mathrm{i}$ årenes løb er alle, der havde med udgivelsen at gøre, afgået ved døden, så han og jeg sad tilbage med færdiggørelsen. I dette arbejde har Iversen båret den største byrde. Færdiggørelsen har ikke været noget morsomt arbejde, men heller ikke her har Iversens pligtfølelse og energi fornægtet sig.

P. Kr. Iversen kan se tilbage på en rig manddomsgerning, der har fortsat sig ind $\mathrm{i}$ »pensionisttilværelsen «. Til ønsket om endnu mange gode år knytter sig håbet om, at Iversen må have lyst og kræfter til at fortsætte sin rige gerning, til gavn for sønderjysk historie, men også til glæde for sig selv. 